\title{
Democratic Peace or Clash of Civilizations? Target States and Support for War in Britain and the United States
}

\author{
Robert Johns University of Essex \\ Graeme A. M. Davies University of Leeds
}

\begin{abstract}
Research on public support for war shows that citizens are responsive to various aspects of strategic context. Less attention has been paid to the core characteristics of the target state. In this comparative study we report survey experiments manipulating two such characteristics, regime type and dominant faith, to test whether the "democratic peace" and the "clash of civilizations" theses are reflected in U.S. and British public opinion. The basic findings show small differences across the two cases: both publics were somewhat more inclined to use force against dictatorships than against democracies and against Islamic than against Christian countries. Respondent religion played no moderating role in Britain: Christians and nonbelievers were alike readier to attack Islamic states. However, in the United States, the dominant faith effect was driven entirely by Christians. Together, our results imply that public judgments are driven as much by images and identities as by strategic calculations of threat.
\end{abstract}

ᄀ he "Bush doctrine" is one of preemption. If force is to be used in response not only to actual but also to potential future threats, the question arises of how such threats are to be identified. One answer is that key characteristics of the target state act as a guide to its likely behavior. In justifications of action in Afghanistan and Iraq, two such characteristics were often invoked. One was the undemocratic nature of the incumbent regimes. Tony Blair expressed his fear "that we wake up one day and we find that one of these dictatorial states has used weapons of mass destruction" (BBC 2004). And, as George W. Bush put it: "we know that dictators are quick to choose aggression, while free nations strive to resolve their differences in peace" (CBS News 2004). This encapsulates the "democratic peace": that democracies rarely go to war with one another (Doyle 1983; Russett 1993). The second, seldom as explicit but often discernible in these leaders' rhetoric, is that these were Islamic countries. Bush notoriously referred to the "war on terror" as a "crusade" (White House 2001), and Blair described the "mutual enmity toward the West" of Islamic extremists and their host regimes (BBC 2004). This calls to mind the "clash of civilizations," a term coined by Samuel Huntington for whom "the most pervasive, important and dangerous conflicts... are along the line separating peoples of Western Christianity, on the one hand, from Muslim and Orthodox people on the other" $(1996,28)$. In short, it appears that U.S. and U.K. elite military decisions are influenced by both the regime type and the dominant faith in the target state.

This article is about public support for war and whether it too is influenced by these factors. Are the democratic peace and clash of civilizations theses also reflected in public decisions about when force is justified? Many studies demonstrate the importance of public backing for military action (e.g., Gartzke 2000; Reiter 2003), and public support was prominent in elite discussion of the Afghanistan and Iraq wars. Here, we adopt a comparative perspective, collecting parallel data from American and British samples. The cases share obvious points in common, being the leading players in Afghanistan and Iraq and having experienced terrorist attacks on their own soil. Yet

Support for this research was provided by the Economic \& Social Research Council (RES-062-23-1952) and Time-Sharing Experiments for the Social Sciences, NSF Grant 0818839, Jeremy Freese and Penny Visser, Principal Investigators. For supplemental material, see the online appendix at http://journals.cambridge.org/jop. Data to reproduce the U.S. analyses are available at www.tessexperiments.org/ data/johns798.html; the U.K. data will be archived at www.esds.ac.uk no later than July 2012.

The Journal of Politics, Vol. 74, No. 4, October 2012, Pp. 1038-1052

doi:10.1017/S0022381612000643

(C) Southern Political Science Association, 2012

ISSN 0022-3816 
there are key differences. Most importantly, religion is both more salient in society and more deeply politicized in the United States than in Britain. The meaning and significance of the "clash of civilizations" is therefore likely to vary between the two.

First, we review research on the determinants of public support for war. Then we examine why the public may be readier to use force against dictatorships rather than democracies, and against Islamic rather than Christian countries. Having set out the data and measures used, we report results showing that both political and religious differences encourage support for military action, with surprisingly little difference between the United States and Britain. Yet this overall similarity is shown to conceal interesting variation in the way that religious affiliation influences opinion in the two cases.

\section{Public Support for War}

One important strand of research into public support for war has concerned the predispositions-the values and principles-that citizens can use to lead them to decisions on foreign policy issues. Prominent among these value dimensions are internationalism versus isolationism (Hurwitz and Peffley 1987; Wittkopf 1990), militarism versus accommodation (Alvarez and Brehm 2002, chap. 9; Holsti 2004), national chauvinism (Herrmann, Isernia, and Segatti 2009), and broader political ideology (Russett, Hartley, and Murray 1994). Clearly, core beliefs and values leave some people strongly predisposed against military action, but others far readier to support it.

Yet predispositions are only part of the story. Most people endorse the use of force under certain circumstances but not others. Public opinion researchers have ceased to see such "inconsistency" as evidence of nonattitudes (Almond 1950; Converse 1964). Rather, it attests to the sensitivity of public opinion to context (Alvarez and Brehm 2002; Zaller 1992). Numerous contextual factors affect public support for military action, both at the outset of the war and as a conflict progresses. Examples include: the objective of military action (Eichenberg 2005; Jentleson 1992); the extent of international backing (Holsti 2004; Kull and Destler 1999) and domestic elite consensus (Larson 1996; Zaller 1992); and casualty rates, especially when the success of the mission seems in doubt (Gartner and Segura 1998; Gelpi, Feaver, and Reifler 2005).

Herrmann, Tetlock, and Visser (1999) use survey experiments to show the impact of both predispositions and situational factors on American public support for military action. They also highlight the interaction between predispositions and context. In their "cognitive-interactionist" framework, the way that people respond to situations depends on their broader attitudes. So we should bear in mind that neither the United States nor the British public is likely to react homogenously to our key variables, target state regime, and dominant faith, when considering the use of force.

In research on the situational factors influencing public support for war, heavy emphasis has been placed on strategic factors such as the objective of military action and the interests at stake. One reason is that the dependent variable in such studies has often been support for ongoing conflicts, whether real (e.g., Jentleson 1992) or hypothetical (Herrmann, Tetlock, and Visser 1999). As such, respondents could base their decisions on the behavior (or "revealed preferences") of the target state. However, in a preemptive context, a state's future behavior and thus the threat it poses have to be inferred from some more static characteristics of that state. Rather less attention has been paid to the way in which the public might draw such inferences.

The most promising theoretical model in this context is what Alexander, Brewer, and Livingston (2005) call "image theory." According to this model, citizens of Country A form images of potential adversary states based on three perceptions: of the relative power of that state vis-à-vis Country $\mathrm{A}$, of the motivations of that state with respect to Country A, and of that state's political culture. With big players on the world stage, these images swiftly become clearly defined and wield a major influence over a range of foreign policy opinions. For example, research on Americans' foreign policy attitudes in the 1980s was dominated by images of the Soviet Union (Hurwitz and Peffley 1990). But with less familiar states, the informational basis for forming international images is likely to be flimsier. In such situations, image formation is likely to be delegated to simple heuristics (Sniderman, Brody, and Tetlock 1991; Zaller 1992). In the next two sections, we explore the notions that regime type and dominant faith could serve as such heuristics and will in turn influence support for using force against that state.

\section{Public Opinion and the Democratic Peace}

That democratic states rarely go to war with one another is "probably the closest thing we have to a law" in international relations (Mintz and Geva 1993, 484). Mor (1997) identifies two basic explanations, 
the institutional/structural and cultural/normative accounts, in both of which public opinion can play a role. This role is particularly central in the first. This model "follows the Kantian premise that democratic consent of the governed serves as a powerful restraint on decisions for war, because it is the citizens who inevitably end up paying the costs" (Dixon 1993, 44). Yet this implies public aversion to war across the board rather than any discrimination by regime type. And, since democracies are no less war-prone overall (Doyle 1983; Rosato 2003), their leaders are plainly not constrained by any pacifism in the mass public. In any case, there appears to be no such tendency. Just when, in Kantian terms, the mobilization of public support should be most difficult, democratic leaders can usually expect a rally-'round-the-flag effect (Lai and Reiter 2005; Mueller 1973). More generally, as noted above, public support for war is not unthinkingly offered or withheld, but depends on circumstances. The question remains: is regime type one of those circumstances?

On the cultural/normative account, states apply democratic norms of behavior-nonviolent conflict resolution and negotiation-in the international as in the domestic arena, and, crucially, can expect other democracies to do the same. In this model, it is the decision-making elites whose norms and negotiations ensure the avoidance of war. Yet mass opinion can still have an important indirect effect. If democratic publics share the view that democratic states share their norms and practices, then they will fear these states less than autocracies and regard military action against democracies as less easily justified (Owen 1997). Equally, if authoritarian regimes do not share democratic norms of nonviolence and are not constrained by public opinion (Dixon 1993; Russett 1993), the domestic public might well conclude that "military might is the only instrument the [authoritarian] adversary will understand and respect, so the use of force is necessary" (Herrmann, Tetlock, and Visser 1999, 555). In turn, insofar as elites' foreign policy decisions are constrained by public preferences, mass opinion helps to maintain the democratic peace.

On that reading, regime type is a heuristic for estimating threat. Another possibility has more to do with the notion of group identities. The public may be reluctant to attack fellow members of the "democratic club" but ready to use force against outsider authoritarian regimes, in line with overwhelming evidence that people are more hostile towards outgroups (Druckman 2001; Kam and Kinder 2007). There, it is the fact that autocracies are different, as much as any inference about their behavior, which drives support for force against them.
In addition to these theoretical considerations, there is some evidence indicating whether the public is readier to use force against nondemocracies. Using convenience samples, Mintz and Geva (1993) ran three survey experiments in which the adversary's regime type was one manipulated feature of a hypothetical conflict situation. Participants in each case were significantly more likely to approve of military action against a nondemocratic state. ${ }^{1}$ Herrmann, Tetlock, and Visser report different experiments in which they manipulated the aggressor country: Iran/ Russia/Israel in one and North Korea/China/Japan in another experiment. They also found that participants were "most willing to use force against the least democratic... and least willing to use force against advanced democracies" (1999, 562). However, since regime type was not explicitly manipulated, it is quite possible that the effects are owed to some other perceived characteristic of those states. The most significant existing evidence for our study comes from a parallel British internet survey experiment, fielded just two months after our own. Tomz and Weeks (2012) present respondents with a scenario in which a foreign state is developing nuclear weapons which it could potentially then launch "against any country in the world." Regime type was one of the details manipulated in the scenario, along with details of the country's military power and alliances. Support for military action against nondemocracies was 13 percentage points higher than for action against democracies. In addition, this gap remained as the other factors were manipulated, suggesting - consistent with a more identity-based interpretation of the democratic peace-that the greater willingness to attack authoritarian regimes is not simply a reflection of strategic calculation.

Our study extends this research in two important comparative directions. First, while Tomz and Weeks (2012) focus on strategic factors, we can compare the effects of regime type with those of dominant faith, testing the relative potency of democracy as a signal or symbol. Second, we run the same experiment in parallel on U.S. and British samples. We therefore report the first experiment with a representative sample of the American public in which the target state's regime type is explicitly manipulated. Moreover, we can compare the effects of regime across the two cases, although in this context we might expect

\footnotetext{
${ }^{1}$ They were also likelier to describe the use of force against a democratic state as a "failure of foreign policy." People may therefore be readier to attack autocracies because they see limited mileage in negotiating with them.
} 
little difference. The United States and the United Kingdom are both established members of the "club of democracies." And, as noted at the outset, recent elite discourse in both countries placed heavy emphasis on the threat from nondemocratic regimes. There seems no reason to expect U.S. and British citizens to react differently to the regime type of the target state. Our hypothesis is therefore:

H1: Citizens in both the United States and Britain are more likely to approve the use of force against authoritarian than against democratic states.

\section{Public Opinion and Target State Religion}

Earlier we quoted Huntington's claim that, following the Cold War, the critical conflicts are likely to pit the Christian and the Muslim worlds against one another. This draws a direct link between religion and foreign policy. While the thesis generated heated debate among academics (e.g., Fox 2001; Russett, Oneal, and Cox 2000), it may well have gone largely unnoticed by the American and British publics during the 1990s. However, the notion of such a clash was thrust into public attention by the attacks of September 11, 2001. And it remained there through the decade, with wars in Afghanistan and Iraq, sporadic attacks by Islamist terrorists on American and British soil, and disputes over religious and cultural symbols. As Smidt puts it, "militant Islam may well have replaced the Soviet Union in the eyes of most Americans as the object of opposition in American foreign policy" (2005, 246). Indeed, there are strong grounds to suspect that both U.S. and British publics will feel more threatened by predominantly Islamic than by predominantly Christian states. This does not entail that such perceptions are accurate. Public perceptions of Islamic states are not objective assessments but reflect the way that those states and that faith have been presented to them by politicians, journalists, priests, and peers (Gershkoff and Kushner 2005; Hunter 1998; Zaller 1992).

Echoing a distinction drawn in the previous section, perceptions of greater threat from Islamic countries could be driven by group identity or by strategic calculation. ${ }^{2}$ Huntington's civilizations may form the basis for group identity, with citizens seeing predominantly Christian countries as the ingroup

\footnotetext{
${ }^{2}$ This distinction should not be overdrawn. There is a complex connection between the cognitive and affective elements of group identity and the perceived threat from an outgroup is likely to be a function of both types.
}

and predominantly Muslim countries as forming the outgroup. Outgroup status can itself be sufficient to generate perceptions of threat and thus in turn lead to greater hostility against Islamic states (Riek, Mania, and Gaertner 2006). Alternatively, British or American citizens may reason (rightly or wrongly) that Islamic states are more prone to acts of unprovoked aggression or to other erratic behavior and hence that military action against them is more likely to be appropriate. This could be based on interpretations of past behavior, such as the assumption that the 9/11 attacks represented a particularly Islamic belligerence. It could, however, be based on an association between Western Christianity and democratic values and, more pertinently, on the belief that Islam and those values are in some way at odds. The latter receives at least prima facie support from the failure of electoral democracy to take hold in the majority of Muslim states (Midlarsky 1998). In that case, while the implication would be the same-greater public readiness to use force against Islamic countries-the driving force would be regime type rather than religion. We can check this by holding regime type constant when manipulating dominant faith (and vice versa). Specifically, we test an interactive hypothesis that the effect of religion depends on regime type: when a country is democratic and so presumably more trustworthy, its dominant faith matters less for support for war.

We know of no research directly testing the proposition that, other things remaining the same, either the American or British publics are more inclined to use force against mainly Islamic than against Christian countries. But indirect evidence points in that direction. It is clear that Muslims are indeed an outgroup-part of what Kalkan, Layman, and Uslaner (2009) call the "band of others"-in American society. They score lower on thermometer scales than other religious minorities (Panagopoulous 2006), and their religion is widely viewed with suspicion (Pew Forum 2009; Smidt 2005, 249-50). Similar patterns emerge in the rather fewer studies of British opinion towards Muslims and Islam (e.g., Wike and Grim 2010). Such patterns are unsurprising given Britain's complicated imperial history in the Middle East (Monroe 1965). Then, the furor surrounding Salman Rushdie's Satanic Verses, when some Muslim protestors burned effigies of Rushdie, fomented a perception of Islam as aggressive and authoritarian (Abbas 2005; Kepel 1997). Thus, the 9/11 attacks and the subsequent London bombings only exacerbated an existing media tendency to characterize a threatening Muslim "other" (Baker 2010; Poynting and Mason 2006). We therefore hypothesize: 
H2: Citizens in both the United States and Britain are more likely to approve the use of force against mainly Islamic than against mainly Christian states;

H3: The effect of dominant faith is reduced when states are democratic.

\section{Religiousness and Reactions to Target State Faith}

In an obvious case of the predisposition-situation interactions described by Herrmann, Tetlock, and Visser (1999), we expect individuals' own religious beliefs and affiliations to influence their reactions to target state religion. It is unclear whether nonreligious people will be more willing to use force against Islamic than against Christian countries, but it is clear that we would expect them to discriminate less in this respect than Christian respondents. Several studies confirm a religious dimension to American public opinion on the recent wars in Iraq and Afghanistan. Support for these interventions was not only stronger among those taking a more negative view of Islam (Smidt 2005) but was also markedly stronger among adherents to Christian denominations than among those disclaiming any such affiliation (Guth 2009).

However, a more detailed scrutiny requires us to move well beyond a crude dichotomy separating "Christians" from the "nonreligious." Among Christian adherents, at least three other distinctions deserve consideration. The first of these is behavioral. In the literature on religion and foreign policy attitudes, relatively little attention has been paid to the question of whether frequency of church attendance or prayer is correlated with a more militarist disposition. An exception, the study of "Messianic Militarism" by Barker, Hurwitz, and Nelson (2008), indicates that the relationship, while weak, is if anything negative, perhaps due to the pacifism preached in many Christian traditions. If that is indeed the reason, it highlights the key point: that attendance betokens stronger commitment to that religious tradition and is liable to intensify the persuasive effects of its teaching. Hence, if we do find that Christians are particularly inclined to discriminate against Islamic states when evaluating military action, we might expect that tendency to be strongest amongst the most frequent attendees.

The second distinction, denomination, has generally explained rather little variation in Americans' foreign policy attitudes (Ribuffo 1998; Wittkopf 1990). Catholics have tended to be slightly less hawkish than "mainline" Protestants, but the differences are minor, and neither group was much different from nonreli- gious respondents in surveys examining approval of the Iraq and Afghanistan wars (Baumgartner, Francia, and Morris 2008; Froese and Mencken 2009; Guth 2009). As the qualifier "mainline" implies, a much more powerful predictor of foreign policy attitudes is the third distinction: belonging to an Evangelical church or identifying as a "born-again" Christian (the two being closely but not perfectly correlated-see Wilcox and Larson (2006) and below). Evangelicals have been found to be markedly more supportive of military action in a range of contexts (Froese and Mencken 2009; Guth 2009; Jelen 1994). The fact that some of this evidence predates 9/11 leads us to expect a "main effect" of Evangelicalism, "born-again" Christians being more supportive of military action regardless of the dominant faith in the target state. Nonetheless, given the politicization of religion in the United States, and especially the strong support for Bush's foreign policy from prominent Evangelicals such as Pat Robertson and James Dobson (Barker, Hurwitz, and Nelson 2008; Durham 2004), we can reasonably expect an interaction with target state faith-that is, "bornagain" Christians disproportionately willing to take action against an Islamic country.

H4: The effect of dominant faith is stronger among Christians than nonreligious citizens.

H5a: The effect of dominant faith is particularly strong among those Christians who attend church frequently.

$H 5 b$ : The effect of dominant faith is particularly strong among those Christians adhering to Evangelical traditions.

The key variables in those hypotheses have implications for our comparison between the United States and the United Kingdom. Religious affiliation is much rarer in Britain than in the United States and, even among those who do report such an affiliation, the large majority attend church rarely or never (Voas and Ling 2010). We might therefore expect the overall effect of target state religion on support for war to be weaker. Moreover, religion is far less politicized in Britain than in the United States. The notion of a "crusade" was absent from British political or religious discourse about the wars in Afghanistan or Iraq. ${ }^{3}$ And there is no significant Evangelical tradition in Britain. Put another way, virtually all Protestants are "mainline" Protestants. There is also much less diversity in terms of denominations. All this considered, we would

${ }^{3}$ It is telling that, in the only multivariate analysis of British attitudes to the Iraq war published to date, religion was not even included as a predictor (Clarke et al. 2009, chap. 4). 
expect the interaction between religious affiliation and target state religion-that is, the "effect of being religious" - to be weaker in Britain than in the United States. We therefore specify the following main hypotheses:

H6: The main effect of dominant faith is weaker in Britain than in the United States;

H7: Any interactions between respondents' religion and dominant faith are weaker in Britain than in the United States.

\section{Data and Measures}

The empirical basis for this study is a 2010 survey experiment conducted in parallel on American and British samples. The U.S. data $(\mathrm{N}=2,075$, response rate $=67.4 \%$ ) were collected in a survey fielded under the auspices of the Time-Sharing Experiments for the Social Sciences (TESS) project. Fieldwork was conducted over the internet by Knowledge Networks (KN). The KN online panel via which TESS surveys are implemented is a probability-based panel, selected using random-digit dial (RDD) and addressbased sampling methods, and is representative of U.S. adults. In order to cover the off-line population, households are provided with access to the internet and hardware if needed.

The British data are taken from Waves 1 and 2 of a major study of foreign policy attitudes (Wave 1: $\mathrm{N}=1,276$, response rate $=62.2 \% ;{ }^{4}$ Wave 2 : $\mathrm{N}=1,065$, retention rate $=83.4 \%$ ). The surveys, like that reported by Tomz and Weeks (2012), were administered over the internet by YouGov, whose approximately 300,000 panel members formed the sampling frame. Unlike KN, YouGov uses an opt-in panel. This is a nonprobability sample-the off-line population is not covered. Hence, we cannot simply pool the U.S. and British data or calculate the statistical significance of differences across the two cases. Instead, we run each analysis in parallel. With this approach, there are reasons to suppose that the results are broadly comparable. Most YouGov panelists are actively recruited rather than volunteering.

\footnotetext{
${ }^{4}$ The response rates are not strictly comparable. Since members of the $\mathrm{KN}$ panel have a known probability of selection, it is feasible to calculate a response rate taking into account all sources of nonresponse, including panel recruitment and retention. With the YouGov opt-in panel, response rates are, in effect, completion rates, representing the proportion of those asked to take part in that survey that agreed to do so.
}

Similarly, respondents cannot choose when to take part: they are either sampled for a given survey or not. And the company's record in predicting vote shares suggests that its sampling and weighting procedures achieve politically representative samples of the British electorate. ${ }^{5}$

\section{Survey Experiment}

The empirical cornerstone of our study is the experiment measuring the impact of target state regime type and dominant faith on willingness to use force. This experiment is based on a vignette presented in the form of a newspaper story. ${ }^{6}$ The story, loosely based on recent debates about Iran but making no explicit reference to that or any other real country, concerns the possibility of launching air strikes on a target state in an attempt to halt a secretive nuclear weapons program. ${ }^{7}$ This vignette captures two key features of Bush-era foreign policy debates: preemption, since the target state has taken no military action; and dispute about the threat, with the very existence of the weapons program a matter of "our government's word against theirs" as far as the public is concerned. Both contribute to uncertainty and thereby increase the usefulness - if not the accuracy — of heuristics such as regime type and dominant faith. The vignette, with manipulations highlighted in bold, is presented below.

This question is about a situation in which Britain might take military action. Please read the

\footnotetext{
${ }^{5}$ There are two further points to note about the British study. First, because the experiment and other questions were embedded into a longer survey, the overall instrument is not the same as that fielded in the United States. But the questionnaires were designed to minimize order effects, with embedded experiments preceded and followed by questions on a different topic. Second, it was fielded a little earlier (Wave 1, 18-19 Jan; Wave 2, 1-8 Feb) than the TESS survey (16-26 Mar). Fortunately, no major foreign policy events occurred in the interim.

${ }^{6}$ This differs from the approach taken in Tomz and Weeks (2012), whereby regime type and other details about the target state were listed as bullet points. We sought to reproduce more closely the way that it would be conveyed to the public. It seems likely that manipulations worked into a newspaper story will generate weaker effects than the blunter bullet-point presentation.

${ }^{7}$ While the generally limited public knowledge about international affairs suggests that the Iranian connection will elude many, prior beliefs about Iran could influence at least some respondents' reactions to the scenario and to the experimental variables. Fortunately, the British survey included a detailed battery of questions about attitudes to Iran. Controlling for these changes none of our substantive findings. While we do not have the measures for a parallel test in the United States, it seems unlikely that a dramatically different pattern would emerge.
} 
following description of that situation and then answer the question below.

"Today the British/American government has presented evidence to the United Nations that Country A has been developing a secret nuclear weapons program which it intends to use against its neighbors in the region. The government is making the case for air strikes against factories associated with this program. Professor Andrew Lincoln, a leading expert on military strategy, has estimated that the planned British/American air strikes would result in the deaths of around one hundred/ three thousand civilians/ [sentence omitted]. The democratically-elected President/unelected dictator of Country A, a predominantly Christian/Islamic country of around 20 million people, has strenuously denied the British government's allegations."

Three aspects of the story were therefore subject to random manipulation: the estimated number of civilian casualties (either not mentioned, 100 or 3,000 ), the regime type (introduced by reference to the head of state: democratically elected President or unelected dictator) and the dominant faith (Christian or Islamic). ${ }^{8}$ In this article, we do not analyze the casualty manipulation, and the results are therefore collapsed across values of that variable. ${ }^{9}$

The newspaper story is followed by two questions providing dependent variables for the upcoming analyses. The second question forces respondents to come down on one side of the fence and provides a simple "percentage support" figure to ease comparisons.

- On a scale from 0 (strongly oppose) to 6 (strongly support), how do you feel about British/American air strikes in this case?

- And if you had to choose "oppose" or "support," which would you go for?

\footnotetext{
${ }^{8}$ Experimental control does not extend to what respondents read into categories like "democracy" or "Islamic." The result is what Tomz and Weeks (2012) call "information leakage," with such terms conveying information about other features of the target state that are also relevant for the dependent variable. Since these features cannot all be manipulated in one experiment, the precise sources of the effects remain hard to pinpoint. Yet information leakage is a substantive as well as a methodological issue. Perhaps it is precisely because citizens infer a good deal from regime type and dominant faith that these factors influence support for war. This does not make the effects any less real or important. Future research should explore in detail the inferences drawn by respondents from such signifiers as "democracy" and "dictatorship" and "Islamic" or "Christian country."

${ }^{9}$ The casualty manipulation is analyzed in a separate article focused on public reactions to civilian casualties. Here, we maintain the focus on target state characteristics.
}

\section{Additional Variables}

The most important individual-level variables in the analyses concern respondent's religious identifications and behavior. In the analyses involving any individual-level religious variables, all of those reporting a non-Christian religious affiliationincluding Muslims-were omitted. The alternative was cells too sparse for useful analysis. Our most basic variable is thus a simple dichotomy: Christian or nonreligious. The same cell size means that we cannot do justice to the rich variety of Christian traditions in the United States. But we can make the key distinctions identified in previous research on religion and foreign policy opinion. In particular, we follow Guth (2009) in distinguishing ethno-religious categories rather than merging what are often very distinct black and white congregations (Steensland et al. 2000). In particular, while many African American Protestants describe themselves as "born again," they may attend churches with a pacifist outlook very different from that in white Evangelical traditions. So we distinguish seven groups: Mainline Protestant; Evangelical Protestant; Black Protestant; White Catholic; Hispanic Catholic; Mormon; and Other Christian. ${ }^{10}$ The equivalent U.K. variable has four categories: Church of England/ Scotland, Catholic, Nonconformist, and Other Christian. The measures of religious attendance differed slightly across the two surveys and so, in order to generate comparable measures, we collapse these into three categories: frequently (once a week or more); occasionally (at least once a year); or nonattendance (less than once a year or never).

One problem in estimating the interactions between predispositional variables (like religious identity) and situational variables (like target state religion) is that these effects may be spurious. The fact that Christians are disproportionately willing to use force against Muslim countries may simply reflect differences in partisanship, ideology, or personality between religious and nonreligious people. Space to measure such differences was very tight on the TESS survey; but it does include the standard 7-point partisanship scale, and we were also able to include three Likert items tapping the core personality variables of nationalism,

\footnotetext{
${ }^{10}$ The Black Protestant and Catholic categories are based on the $\mathrm{KN}$ measures of ethnicity and denomination. However, when it comes to white Protestants, the latter variable conflates mainline and Evangelical strands within broad categories such as "Baptist" or "Other Protestant." To differentiate mainline and Evangelical Protestants, we used a follow-up question in which respondents reporting a Christian affiliation were asked "Would you describe yourself as a born-again or evangelical Christian?"
} 
authoritarianism, and social dominance orientation (SDO). All three would be expected to predict discrimination between target states and all three are associated with - and might be thought of as causally prior to-religious affiliation (Altemeyer 2003; Hunsberger 1995; McFarland 2005). These single items are obviously crude measures of the underlying orientations but, together, they go some way to controlling for those aspects of personality that might generate spurious effects of respondent religion.

- [Nationalism] "Generally speaking, Britain/America is better than other countries."

- [Authoritarianism, reverse scored] "People in Britain/ America should be more tolerant of those who lead unconventional lives."

- [Social dominance] "Some people are just more deserving than others."

\section{Results}

We present the results in three sections. First, using the dichotomous dependent variable, we analyze how the percentage support for military action depends on our experimental variables. Second, for more complex models testing interactions between situational variables and respondent religion, we turn to ANOVA based on the 7-point scale dependent variable. In the third section, we focus only on Christian respondents, assessing whether aspects of their religious identifications and behavior moderate reactions to target state faith.

\section{Main Effects of Regime Type and Dominant Faith}

In Table 1 we report the percentage of U.S. and British respondents that opted to support military action against Country A, broken down first by regime type and dominant faith separately and then by the two in interaction. For the main effects, we also report two simple measures of effect size: the percentage difference in support, and phi, a measure of correlation between these dichotomous variables.

The first point to note is that the American public is noticeably more hawkish than the British. This cross-national difference is fairly consistent across experimental conditions and is also wider than the differences generated by the experimental variables. Nonetheless, there is clear support for $\mathrm{H} 1$ and $\mathrm{H} 2$. In
Table 1 Percentage Support for Air Strikes by Regime Type and Dominant Faith across Countries

\% Supporting Air Strikes

US Britain

\begin{tabular}{lcc} 
Regime Type & & \\
Democracy & 44.7 & 34.7 \\
Dictatorship & 49.4 & 41.0 \\
\% difference & 4.7 & 6.3 \\
Phi & $0.05^{\star *}$ & $0.07^{\star *}$ \\
& & \\
Dominant Faith & & \\
$\quad$ Christian & 43.5 & 34.8 \\
Islamic & 50.6 & 41.1 \\
\% difference & 7.1 & 6.3 \\
Phi & $0.07^{\star *}$ & $0.07^{\star *}$ \\
Regime Type * Dominant Faith & \\
Christian democracy & 41.7 & 29.3 \\
Christian dictatorship & 45.3 & 40.4 \\
Islamic democracy & 47.9 & 40.7 \\
Islamic dictatorship & 53.2 & 41.7 \\
$\mathrm{~N}$ & 2035 & 1268 \\
\hline
\end{tabular}

Note: ${ }^{\star}=p<0.1 ;{ }^{* *}=p<0.05 ;{ }^{* *}=p<0.01$.

both countries, respondents were significantly more likely to support military action against dictatorships than against democracies and against mainly Islamic than against mainly Christian states. For the British public, the regime type effect is noticeably smaller than that reported by Tomz and Weeks (2012), possibly for the methodological reasons noted above. Nonetheless, both the democratic peace and the clash of civilizations find reflections in American and British public attitudes to the use of force.

We did not anticipate U.S.-British differences in the effect of regime type and the results bear out that null hypothesis: if the democracy-dictatorship gap is slightly wider in the United Kingdom, the difference is negligible. But we did hypothesize that the American public would be more influenced by target state faith (H6), and so here the similarity across cases is more surprising. Judging by the phi coefficients, the effect of dominant faith is as strong in Britain as in the United States. (The percentage difference is slightly smaller with the British data but only because all percentages are smaller in more pacific Britain.) This is a striking finding given the lower salience of religion in British politics and society, a point we return to in the conclusion. 
We turn now to the interaction between these two variables, as shown in the final rows of the table. In $\mathrm{H} 3$, we suggested that dominant faith would matter less with democratic states, on the Huntingtonian grounds that the key difference between Western and Muslim civilizations lies in the latter's rejection of the democratic values (see Norris and Inglehart 2002). This hypothesis can be dismissed. Both publics were significantly more supportive of action against Islamic democracies than Christian democracies. Furthermore, both proved as willing to attack Islamic democracies as to attack Christian dictatorships. If anything, dominant faith trumps regime type, especially in the United States. In Britain, there was a subtler pattern, although again opposite to that hypothesized. Regime type mattered a good deal for Christian states but hardly at all for Islamic states. For many in the British public, Christianity and democracy both look like necessary conditions for target states to elicit a dovish reaction.

\section{Regime Type, Dominant Faith, and Respondent Religion}

The basis for this section is the three ANOVAs in Table 2 . The first includes only the variables-regime type and dominant faith-analyzed just above. ${ }^{11}$ It enables us to retest the core hypotheses $\mathrm{H} 1-\mathrm{H} 3$ using the 7-point scale dependent variable-including formal tests of the interactions between the factors - and also provides a baseline for comparison with subsequent models. In the second model, we introduce respondent's religious affiliation and test the interactions posited in H4. For the third model, we add partisanship and the Likert personality items in order to gauge whether this weakens the effects of respondent religion. With each analysis, we report the F-statistics (and accompanying significance values) and partial eta $(\eta)$, a measure of effect size comparable to a standardized regression coefficient.

For the British, Model 1 reinforces the findings from Table 1. Both regime type and dominant faith have significant effects on support for military action, and the effects are broadly similar in size. However, the conclusions about the United States have changed somewhat. When respondents were given a scale rather than forced to "support" or "oppose," the stronger impact of dominant faith shows through. This applies

\footnotetext{
${ }^{11}$ These models also include basic sociodemographic controls: for age, gender, and education. To save space in Table 2, coefficients for the control variables are reported in Table A1 in the online appendix.
}

to some extent when comparing across countries: the dominant faith effect looks stronger in the United States $(\eta=0.09)$ than in Britain $(\eta=0.06)$. Yet there remains little support for $\mathrm{H} 6$ - the transatlantic differences are small. The more striking (and statistically significant) difference is across variables. While dominant faith and regime type had roughly equal influence over the British public, the American public's decisions were clearly driven more by religion $(\eta=0.09)$ than regime $(\eta=0.03)$. So the effect suggested in $\mathrm{H} 2$ is significant in both countries but stronger in the United States, but the effect posited in $\mathrm{H} 1$ is significant only in Britain. Meanwhile, H3 can be definitively rejected since there is no sign in either country of an interaction between regime and dominant faith. One final point to note is that neither of the experimental variables shows a particularly strong effect, with partial $\eta$ s below 0.1 (and thus partial $\eta^{2}$ s below 0.01). As a result, the proportion of variance explained by the overall model is very small ( $\mathrm{R}^{2}$ in Britain being boosted mainly by the demographic controls). We return to the issue of effect size in concluding the article.

Introducing respondents' religion-via the "Christian or nonreligious" dichotomy-into the model (Model 2) has a very different impact in the two cases. In the United States, the main effect of target state faith is reduced to nonsignificance (though it appears nonnegligible in size) while there is a significant interaction between dominant faith and respondent religion. In other words, the main reason for Americans' relative reluctance to attack Christian nations is that many respondents are self-identified Christians. By contrast, in the United Kingdom, the main effect of target state faith is undiminished when respondent religion is controlled and the predispositions themselves have no significant effect. Clash of civilizations discourse seems to have traction with at least some British people, regardless of their own religious affiliation. British Christians were no more likely than their secular compatriots to discriminate between Islamic and Christian states in assessing military action. In short, $\mathrm{H} 4$ receives clear support in the U.S. public but none in Britain, and $\mathrm{H} 7$ is supported because a clear interaction between respondent religion and dominant faith in the United States is not significant in Britain

Before exploring these contrasting effects of respondent religion, it is worth checking whether they simply reflect broader differences in political outlook. Partisanship and the items tapping nationalism, authoritarianism, and SDO are introduced in Model 3. As expected, all are significant predictors of support for military action. The more pressing 
TABle 2 Analyses of Variance in Support for Air Strikes by Regime Type, Dominant Faith, Respondent Religion and Attitudinal Controls

\begin{tabular}{|c|c|c|c|c|c|c|c|c|c|c|c|c|}
\hline & \multicolumn{4}{|c|}{ Model 1} & \multicolumn{4}{|c|}{ Model 2} & \multicolumn{4}{|c|}{ Model 3} \\
\hline & \multicolumn{2}{|c|}{ USA } & \multicolumn{2}{|c|}{ Britain } & \multicolumn{2}{|c|}{ USA } & \multicolumn{2}{|c|}{ Britain } & \multicolumn{2}{|c|}{ USA } & \multicolumn{2}{|c|}{ Britain } \\
\hline & $\mathbf{F}$ & $\eta$ & $\mathbf{F}$ & $\eta$ & $\mathbf{F}$ & $\eta$ & $\mathbf{F}$ & $\eta$ & $\mathbf{F}$ & $\eta$ & $\mathbf{F}$ & $\eta$ \\
\hline Target regime & 1.2 & 0.03 & $4.0^{* *}$ & 0.06 & 0.9 & 0.02 & $4.3^{* *}$ & 0.06 & 0.8 & 0.02 & $3.3^{*}$ & 0.06 \\
\hline Target faith & $16.7^{\star * *}$ & 0.09 & $3.6^{\star}$ & 0.06 & 2.2 & 0.03 & $3.4^{\star}$ & 0.06 & 2.4 & 0.03 & $3.3^{*}$ & 0.06 \\
\hline Target faith $*$ Target regime & 0.4 & 0.01 & 0.7 & 0.03 & 0.3 & 0.01 & 0.8 & 0.03 & 0.0 & 0.00 & 0.8 & 0.03 \\
\hline Christian & & & & & $11.9^{\star * *}$ & 0.08 & 1.7 & 0.04 & 0.0 & 0.00 & 1.3 & 0.03 \\
\hline Target faith ${ }^{\star}$ Christian & & & & & $4.0^{\star \star}$ & 0.05 & 0.0 & 0.00 & $5.2^{* \star}$ & 0.05 & 0.1 & 0.01 \\
\hline Party identification & & & & & & & & & $24.7^{\star \star \star \star}$ & 0.11 & 5.5 & 0.12 \\
\hline Authoritarianism & & & & & & & & & $39.7^{\star * *}$ & 0.17 & $23.6^{* * *}$ & 0.14 \\
\hline Nationalism & & & & & & & & & $126.3^{* * *}$ & 0.27 & $13.5^{\star * *}$ & 0.11 \\
\hline Social dominance & & & & & & & & & $16.2^{\star * \star}$ & 0.09 & $3.4^{\star}$ & 0.06 \\
\hline $\mathrm{R}^{2}$ (adj.) & \multicolumn{2}{|c|}{0.019} & \multicolumn{2}{|c|}{0.048} & \multicolumn{2}{|c|}{0.025} & \multicolumn{2}{|c|}{0.048} & \multicolumn{2}{|c|}{0.151} & \multicolumn{2}{|c|}{0.096} \\
\hline $\mathrm{N}$ & \multicolumn{2}{|c|}{1,972} & \multicolumn{2}{|c|}{1,054} & \multicolumn{2}{|c|}{1,972} & \multicolumn{2}{|c|}{1,054} & \multicolumn{2}{|c|}{1,972} & \multicolumn{2}{|c|}{1,054} \\
\hline
\end{tabular}

Note: In order to maintain comparability across the models, we use listwise deletion to test all three on the same sample. The authoritarianism and social dominance items appeared in the second wave of the British study, and so that sample reflects the attrition between the first and second waves. We also tested the simpler models on the larger (Wave 1 only) sample and the results-available from the authors on request-were virtually identical.

${ }^{\star}=p<0.1 ;{ }^{* *}=p<0.05 ;{ }^{* *}=p<0.01$.

question here is whether the target regime and target faith effects persist when these more general orientations are controlled; and the answer is that they do. There remain main effects of regime type and dominant faith in Britain but not the United States, and there remains an interaction between target state faith and respondent religion in the United States but not in Britain. The greater willingness to use force against Islamic countries is not driven just by partisanship, nationalism, or authoritarianism. The most noticeable effect of introducing these variables is to eliminate what had been a strong main effect of respondent religion in the United States. The reason why American Christians were more hawkish is not because they are religious; it is because they are more likely to be Republicans, and more prone to generalized prejudice and a belief that some groups can legitimately dominate others.

Having established that the effects of dominant faith are robust against these attitudinal controls, we now illustrate the different patterns of results across the two countries. Figure 1 shows how mean support for action varies by dominant faith and respondent religion in the United States and Britain. Error bars are included, indicating the $95 \%$ confidence interval around each mean value. While the effect sizes are not striking, the contrast is clear. Among the British public, the effect of target state religion does not differ by respondent religion. Both Christians and nonreligious respondents are somewhat more likely to support this action against an Islamic state than against a Christian state. By contrast, Christians and nonreligious citizens in the United States react differently to target state religion. While American Christians were noticeably more likely to support the use of force against a predominantly Islamic than against a Christian state, their nonreligious counterparts show signs of discriminating in the other direction (although, partly due to the small numbers of secular Americans,

\section{Figure 1 Mean Support for Air Strikes by Dominant Faith and Respondent Religion across Countries}

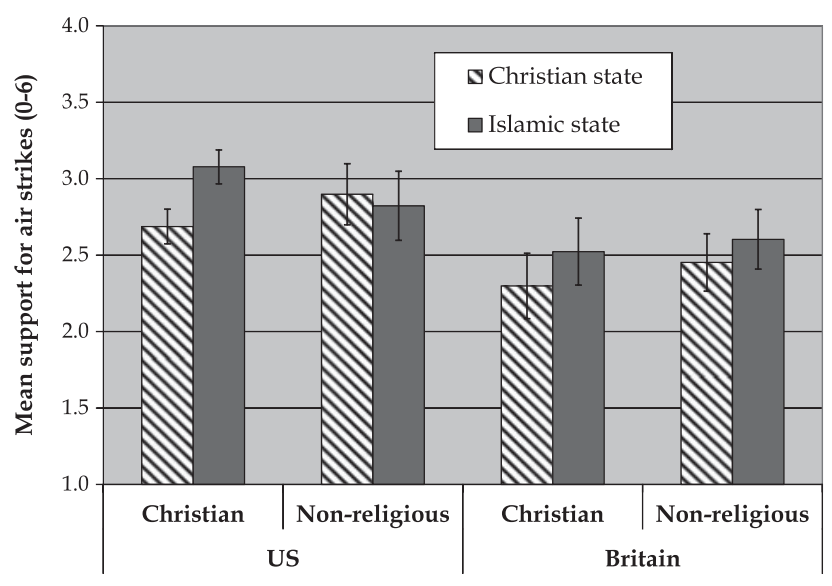


the confidence intervals overlap in the latter case). In the concluding section, we discuss possible reasons why nonreligious respondents react differently in the two countries.

\section{Christians' Reactions to Dominant Faith}

Next, we test two further models on the British and American Christian subsamples. In the first of these, the three-category measure of church attendance is added. We know from previous analyses that there is a main effect of target state faith among both American and British Christians. These effects remain significant and relatively strong in Model 4 (in Table 3), confirming that such discrimination is not confined to frequent churchgoers or, for that matter, to nonpractising Christians. In the United States, there is no support for H5a: religious attendance plays little or no role. Contrary to
H7, the moderating effects of religious behavior are actually stronger-and significant only-in Britain. Figure 2 illustrates these effects. One point, namely that more frequent attendees are particularly influenced by dominant faith, might have been expected. However, this is driven by greater reluctance to attack Christian states than by greater willingness to attack Islamic states. Church attendance in Britain seems to generate solidarity with fellow Christians rather than a general commitment to pacifism. In the United States, there is the hint of an effect, with the least frequent attendees also the least likely to discriminate by target state faith. While that interaction is not statistically significant, it does suggest that a further breakdown by religious identification may yield significant differences-that is, that attendance at certain churches does drive discrimination by target state faith.

Table 3 Analyses of Variance in Support for Air Strikes by Regime Type, Dominant Faith, and Religious Variables-Christian Respondents Only

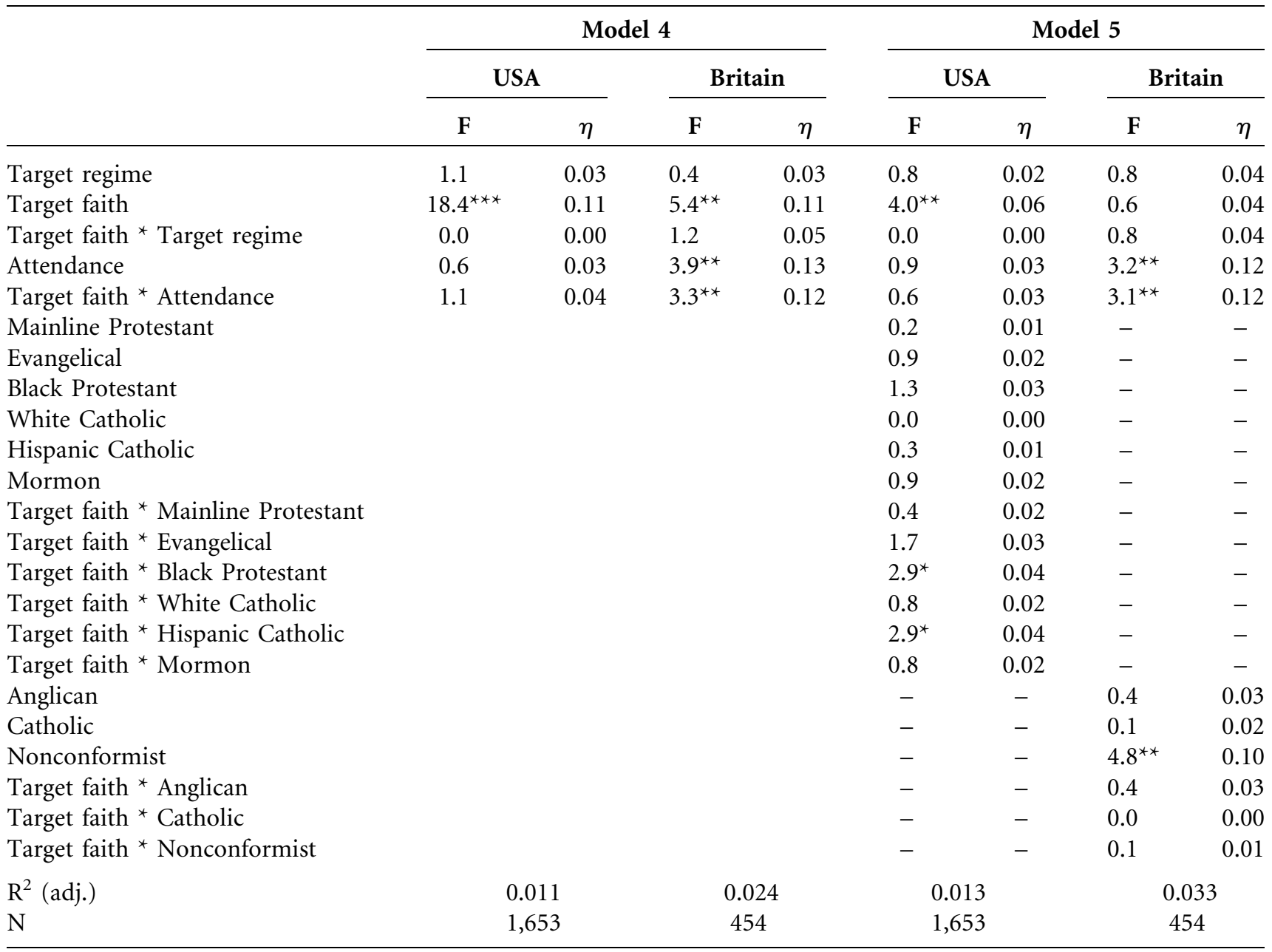

Note: ${ }^{\star}=p<0.1 ;{ }^{* *}=p<0.05 ;{ }^{* * *}=p<0.01$. 


\section{Figure 2 Mean Support for Air Strikes by Dominant Faith and Religious Attendance across Countries-Christian Respondents Only}

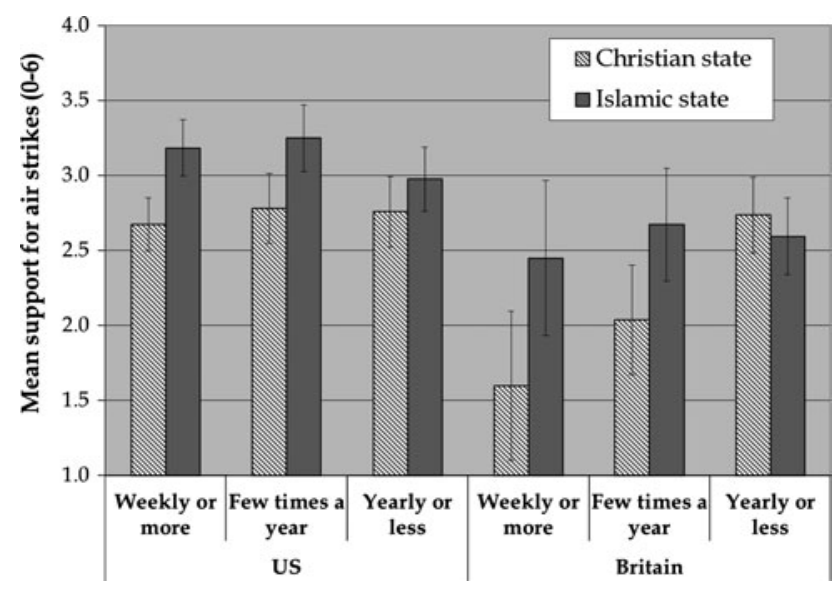

To explore that possibility, we estimated Model 5 in which denominational variables are added. The reference group is the residual category of "Other Christians." The first point to note is the dearth of significant effects. Nonetheless, as the $\mathrm{R}^{2}$ values show, the few differences among Christians are again stronger in Britain. The effects of attendance from Figure 2 remain and are of similar size. Denomination also has a main effect-mean support being significantly lower among nonconformists (1.69) than among any of the other three groups (the mean for the Anglican majority being 2.35) - but shows no interaction with target state faith. The denominations vary in general willingness to take military action rather than willingness to take action against particular types of target state.

The more striking results are the null findings from the U.S. analysis. We do not see main effects of the kind that previous research on religionEvangelicalism in particular-and militarism would imply. Second, none of the interactions are significant at the $95 \%$ level. The largest partial eta remains the main effect of dominant faith, suggesting little heterogeneity in Christians' reactions to the manipulation. ${ }^{12}$ There is at least some sign that Evangelical Protestants are more militarist, both in general and especially against Islamic states, than mainline Prot-

\footnotetext{
${ }^{12}$ The results by denomination are illustrated in Figure A1 in the online appendix. It shows mean support for force by target state faith among each of the five religious categories with an $\mathrm{N}$ of over 100
}

estants. But, even on a generous $p<0.10$ criterion, $\mathrm{H} 5 \mathrm{~b}$ is rejected. ${ }^{13}$ The chief contrast within the U.S. public is not among Christians but between Christians and the nonreligious. The reverse is true of the British.

\section{Conclusion}

Jentleson (1992) characterized the American public as "pretty prudent" when it came to support for war. Judgments about the use of force looked to be based sensibly and predictably on factors such as the central objective of military action and the extent of American interests at stake. The regime type effects observed in our study tend to support Jentleson's argument (and suggest also that prudence extends to the British public). Assuming that theorists of the democratic peace are correct, authoritarian regimes pose more threat to democracies than do other democracies, and so the public's greater willingness to take action against dictatorships looks like rational preemptive self-defense.

It is more debatable whether the discrimination by target state religion-a stronger effect than that of regime-can also be seen as prudent or rational. Dominant faith was not simply used as a cue to gauge regime type: respondents were readier to use force against Islamic than Christian states, regardless of their political make-up. Indeed, both the U.S. and British publics were slightly more hawkish against Islamic democracies than against Christian dictatorships. This could be seen as reasonable given that, "from a Western perspective, the proportion of civilizational conflicts involving Western groups that are with Islamic groups increased dramatically after the end of the Cold War" (Fox 2001, 459). Citizens may believe this conflict to have reached a point where, even if Islamic states are internally democratic, they cannot be relied upon to observe democratic norms on the world stage. Yet there are actually few examples of Islamic states-let alone Islamic democracieslaunching the kind of attack hinted at in the vignette. The fact that dominant faith mattered more to the public than regime type clashes with the evidence

\footnotetext{
${ }^{13}$ To test the robustness of this null finding, we tried two other specifications: Model 6, with a three-way interaction between target state faith, attendance, and denomination; and Model 7, in which we dropped denominations and used only the subjective "born again" dichotomy. The interaction between Evangelicalism and target state faith remains stubbornly nonsignificant. These results are in Table A2 in the online appendix.
} 
reported by Russett, Oneal, and Cox (2000) that the democratic peace thesis remains a much better predictor of interstate conflict than is the clash of civilizations.

Whether or not discrimination against Islamic target states is rational, it is worth noting that image theory (Alexander, Brewer, and Livingston 2005) provides a straightforward alternative account. Images of international actors are based not (only) on their behavior but also on subjective judgments about their norms and motivations. Those judgments are highly likely to be biased along the lines of group identities. Thus, the more that religion becomes a salient basis for group identity, the more likely that citizens will attribute malign motivations to those-whether individuals or states - of other religions and, in turn, feel less compunction about acting to combat that threat. This seems to us a reasonable characterization of the way public opinion has reacted to Islam since the 9/11 attacks. To reiterate: this account does not imply that Islamic states really do pose more of a threat than Christian states or than they did 20 years ago. The point is that a process of image (re)construction has led at least some citizens to believe that. This notion of construction highlights the power held by elites and other opinion leaders. The conduct of adversaries can of course be framed and interpreted in different ways, but ultimately it is difficult to pretend military action has happened when it has not, or vice versa. It is easier to construct a negative image around a signifier like Islam, intensifying perceptions of threat and creating expectations of future behavior. ${ }^{14}$ In a preemptive context, that sense of threat may convince the public to endorse military action.

We should not overstate the power of elite framing, however. Neither of our experimental variables explained large portions of the variation in support for military action. That said, it is worth noting that the percentage differences here are similar to those reported by Herrmann, Tetlock, and Visser (1999) in experiments manipulating other features-notably the power and motivations - of the target state. Those authors observed markedly stronger effects when manipulating the extent to which "home" (in that case, United States) interests were at stake. On the other hand, both regime type and dominant faith had slightly stronger effects in our experiment than did the civilian casualty manipulation that was also included.

\footnotetext{
${ }^{14}$ In this sense, our experimental findings probably understate dominant faith effects. We simply mentioned the word "Islamic" or "Christian"; politicians, journalists, and church leaders may use those terms as the basis for building much richer images, positive or negative, that would have a more powerful influence on public opinion.
}

Turning to the comparative side of our analysis, our expectations were often confounded. While we predicted that target state religion would matter more to the Americans, it seems that the British have a similarly negative image of Islamic states' motivations and behavior. As noted earlier, this is consistent with representations of Muslims in the British media. If it still seems counterintuitive, given the markedly lower salience of religion in British politics and society, the explanation is clear enough: negativity towards Islam in Britain was not driven by (respondents') religion. Discrimination by target state religion was as strong among nonreligious people as among Christians. Perhaps, with religion less salient and less entangled with national identity than in the United States, the British public interpreted an event like the July $7^{\text {th }}$ bombings in London as an Islamic attack on the nation, whereas the American public interpreted 9/11 as an attack not just on the United States but on Christianity. That argument gains support from another notable result, namely the homogeneity of U.S. Christians' reactions to target state faith. There was little indication that Evangelicals were more militarist in general, or inclined to attack Islamic states in particular. Any such effects were much weaker than the tendency among Christians as a whole to discriminate by target state religion.

That still leaves the question of why nonreligious citizens in the two countries reacted differently. Why didn't secular Americans discriminate against Islamic states in the way their British counterparts did? The likeliest explanation again lies in the differing salience of religion. In Britain, ties between religion and politics-including foreign policy_are few and loose, and there is no major religious-secular divide. As a result, being "nonreligious" is rarely a key facet of political identity. In the United States, by contrast, where religious affiliates are the clear majority and many highly charged debates pit secular against religious opinion, being a non-Christian is more likely to constitute a positive group identity (rather than simply the absence of religious identity). Christians, notably Evangelical Protestants, are the outgroup to this secular ingroup, and attitudes between the two have polarized. So, if a prominent characteristic of Christian thinking on foreign policy is to discriminate against Islamic states, we would expect nonreligious Americans to react against that kind of discrimination.

Future research should address the perceptual variables explaining why the public is readier to take action against autocracies and Islamic states. It would also be instructive to test whether the relative 
importance of regime type and religion varies across different military scenarios. But perhaps the most important requirement for further research is time. Perhaps discrimination by regime type is a persistent feature of foreign policy opinion while discrimination by dominant faith is a sign of recent times. However, once established, a negative image can take a long time to wear off. For now, if U.S. and British governments are trying to generate support for military action against Islamic states-whatever their regime typethen the religion card looks a worryingly useful one to play.

\section{Acknowledgments}

We are grateful to Jeremy Freese, Penny Visser, Michael Tomz, Jessica Weeks, David Barker, George Marcus, and the anonymous reviewers for their comments and suggestions.

\section{References}

Abbas, Tahir. 2005. Muslim Britain: Communities under Pressure. New York: Zed Books.

Alexander, Michele G., Marilynn B. Brewer, and Robert W. Livingston. 2005. "Putting Stereotype Content in Context: Image Theory and Interethnic Stereotypes." Personality and Social Psychology Bulletin 31 (6): 781-94.

Almond, Gabriel. 1950. The American People and Foreign Policy. New York: Harcourt Brace.

Altemeyer, Robert. 2003. "Why Do Religious Fundamentalists Tend to be Prejudiced?" The International Journal for the Psychology of Religion 13: 17-28.

Alvarez, R. Michael, and John Brehm. 2002. Hard Choices, Easy Answers. Princeton, NJ: Princeton University Press.

Baker, Paul. 2010. "Representations of Islam in British Broadsheet and Tabloid Newspapers 1999-2005," Journal of Language and Politics 9 (2): 310-38.

Barker, David C., Jon Hurwitz, and Traci L. Nelson. 2008. "Of Crusades and Culture Wars: 'Messianic' Militarism and Political Conflict in the United States." Journal of Politics 70: $307-22$.

Baumgartner, Jody C., Peter L. Francia, and Jonathan S. Morris, 2008. "A Clash of Civilizations? The Influence of Religion on Public Opinion of U.S. Foreign Policy in the Middle East." Political Research Quarterly 61: 171-79.

BBC. 2004. Blair terror speech in full. BBC News, March 5. http:// news.bbc.co.uk/1/hi/uk_politics/3536131.stm (accessed August $28,2010)$.

Clarke, Harold D., David Sanders, Marianne C. Stewart, and Paul Whiteley. 2009. Performance Politics and the British Voter. Cambridge: Cambridge University Press.

CBS News, 2004. Text of Bush's Speech to the UN. World News, September 21. http://www.cbsnews.com/stories/2004/09/21/ world/main644795.shtml (accessed August 28, 2010).
Converse, Philip E. 1964. "The Nature of Belief Systems in Mass Publics." In Ideology and Discontent, ed. David Apter. New York: Free Press, 206-69.

Dixon, William J. 1993. "Democracy and the Management of International Conflict." Journal of Conflict Resolution 37 (1): $42-68$.

Doyle, Michael W. 1983. "Kant, Liberal Legacies, and Foreign Affairs: Parts One and Two." Philosophy and Public Affairs 12 (2/3): 205-35, 323-53.

Druckman, Daniel. 2001. "Nationalism and War: A SocialPsychological Perspective." In Peace, Conflict and Violence, ed. Daniel J. Christie, Richard V. Wagner, and Deborah Du Nann Winter. Upper Saddle River, NJ: Prentice-Hall, 49-65.

Durham, Martin. 2004. "Evangelical Protestantism and Foreign Policy in the United States after September 11." Patterns of Prejudice 38 (2): 146-58.

Eichenberg, Richard C. 2005. "Victory has Many Friends: U.S. Public Opinion and the Use of Military Force, 1981-2005." International Security 30 (1): 140-77.

Fox, Jonathan. 2001. "Two Civilizations and Ethnic Conflict: Islam and the West." Journal of Peace Research 38 (4): 459-72.

Froese, Paul, and F. Carson Mencken. 2009. "A U.S. Holy War? The Effects of Religion on Iraq War Policy Attitudes." Social Science Quarterly 90: 103-16.

Gartner, Scott Sigmund, and Gary M. Segura. 1998. "War, Casualties and Public Opinion." Journal of Conflict Resolution 42 (3): 278-300.

Gartzke, Erik. 2000. "Preferences and the Democratic Peace." International Studies Quarterly 44 (2): 191-210.

Gelpi, Christopher, Peter D. Feaver, and Jason Reifler. 2005-6. "Success Matters: Casualty Sensitivity and the War in Iraq." International Security 30 (3): 7-46.

Gershkoff, Amy, and Shana Kushner, 2005. "Shaping Public Opinion: The 9/11-Iraq Connection in Bush Administration Rhetoric." Perspectives on Politics 3 (3): 525-37.

Guth, James L. 2009. "Militant and Cooperative Internationalism among American Religious Publics." Presented at the BISA Working Group Conference on US Foreign Policy, Norwich, UK.

Herrmann, Richard K., Philip E. Tetlock, and Penny S. Visser. 1999. "Mass Public Decisions to Go to War: A CognitiveInteractionist Framework." American Political Science Review 93 (3): 553-73.

Herrmann, Richard K., Pierangelo Isernia, and Paolo Segatti. 2009. "Attachment to the Nation and International Relations: Dimensions of Identity and their Relationship to War and Peace." Political Psychology 30 (5): 721-54.

Holsti, Ole R. 2004. Public Opinion and American Foreign Policy. Ann Arbor: University of Michigan Press.

Hunsberger, Bruce. 1995. "Religion and Prejudice: The Role of Religious Fundamentalism, Quest, and Rightwing Authoritarianism." Journal of Social Issues 51: 113-29.

Hunter, Shireen T. 1998. The Future of Islam and the West: Clash of Civilizations or Peaceful Coexistence? Westport, CT: Praeger.

Huntington, Samuel P. 1996. The Clash of Civilizations and the Remaking of World Order. New York: Simon and Schuster.

Hurwitz, Jon, and Mark Peffley. 1987. "How Are Foreign Policy Attitudes Structured?" American Political Science Review 81 (4): 1099-1120.

Hurwitz, Jon, and Mark Peffley. 1990. "Public Images of the Soviet Union: The Impact on Foreign Policy Attitudes." Journal of Politics 52 (1): 3-28. 
Jelen, Ted G. 1994. "Religion and Foreign Policy Attitudes: Exploring the Effects of Denomination and Doctrine." American Politics Research 22 (3): 382-400.

Jentleson, Bruce W. 1992. "The Pretty Prudent Public: Post PostVietnam American Opinion on the Use of Military Force." International Studies Quarterly 36 (1): 49-73.

Kalkan, Kerem, Geoffrey Layman, and Eric M. Uslaner. 2009. "'Bands of Others?' Attitudes toward Muslims in Contemporary American Society.” Journal of Politics 71 (3): 1-16.

Kam, Cindy D., and Donald R. Kinder. 2007. "Terror and Ethnocentrism: Foundations of American Support for the War on Terrorism." Journal of Politics 69 (2): 320-38.

Kepel, Gilles. 1997. Allah in the West: Islamic Movements in America and Europe. Stanford, CA: Stanford University Press.

Kull, Steven, and I. M. Destler. 1999. Misreading the Public: The Myth of a New Isolationism. Washington, DC: Brookings.

Lai, Brian, and Dan Reiter. 2005. "Rally Round the Union Jack? Public Opinion and the Use of Force in the UK, 1948-2001." International Studies Quarterly 49: 255-72.

Larson, Eric V. 1996. Casualties and Consensus: The Historical Role of Casualties in Domestic Support for U.S. Military Operations. Santa Monica, CA: RAND.

Lippmann, Walter. 1922. Public Opinion. New York: Free Press.

McFarland, Sam G. 2005. "On the Eve of War: Authoritarianism, Social Dominance, and American Students' Attitudes toward Attacking Iraq." Personality and Social Psychology Bulletin 31: 360-67.

Midlarsky, Manus I. 1998. "Democracy and Islam: Implications for Civilizational Conflict and the Democratic Process." International Studies Quarterly 42 (3): 485-511.

Mintz, Alex, and Nehemia Geva. 1993. "Why Don't Democracies Fight Each Other? An Experimental Study." Journal of Conflict Resolution 37 (2): 484-503.

Monroe, Elizabeth. 1965. Britain's Moment in the Middle East. London: Cox \& Wyman.

Mor, Ben D. 1997. "Peace Initiatives and Public Opinion: The Domestic Context of Conflict Resolution." Journal of Peace Research 34 (2): 197-215.

Mueller, John E. 1973. War, Presidents and Public Opinion. New York: Wiley.

Norris, Pippa, and Ronald Inglehart. 2002. "Islamic Culture and Democracy: Testing the 'Clash of Civilizations' Thesis." Comparative Sociology 1 (3-4): 235-63.

Owen, John M. 1997. Liberal Peace, Liberal War: American Politics and International Security. Ithaca, NY: Cornell University Press.

Panagopoulos, Costas. 2006. "The Polls-Trends Arab and Muslim Americans and Islam in the Aftermath of 9/11." Public Opinion Quarterly 70 (4): 608-24.

Pew Forum. 2009. Muslims Widely Seen as Facing Discrimination. 9 September. http://pewforum.org/PublicationPage.aspx?id= 1398 (accessed August 28, 2010).

Poynting, Scott, and Victoria Mason. 2006. "Tolerance, Freedom, Justice and Peace? Britain, Australia and Anti-Muslim Racism since 11 September 2001." Journal of Intercultural Studies 27 (4): 365-92.

Reiter, Dan. 2003. "Exploring the Bargaining Model of War." Perspectives on Politics 1 (1): 1-17.
Ribuffo, Leo. 1998. "Religion and American Foreign Policy." National Interest 52: 36-51.

Riek, Blake M., Eric W. Mania, and Samuel L. Gaertner. 2006. "Intergroup Threat and Outgroup Attitudes. "Personality and Social Psychology Review 10: 336-53.

Rosato, Sebastian. 2003. "The Flawed Logic of Democratic Peace Theory.” American Political Science Review 97 (4): 585-602.

Russett, Bruce. 1993. Grasping the Democratic Peace. Princeton, NJ: Princeton University Press.

Russett, Bruce, Thomas Hartley, and Shoon Murray. 1994. "The End of the Cold War, Attitude Change and the Politics of Defense Spending." PS: Political Science and Politics 27 (1): $17-21$.

Russett Bruce, M., John R. Oneal, and Michaelene Cox. 2000. "Clash of Civilizations, or Realism and Liberalism Déjà $V u$ ?" Journal of Peace Research 37 (5): 583-608.

Smidt, Corwin. 2005. "Religion and American Attitudes towards Islam and an Invasion of Iraq." Sociology of Religion 66: 243-61.

Sniderman, Paul M., Richard A. Brody, and Philip E. Tetlock. 1991. Reasoning and Choice: Explorations in Political Psychology. Cambridge: Cambridge University Press.

Steensland, Brian, Jerry Z. Park, Mark D. Regnerus, Lynn D. Robinson, W. Bradford Wilcox, and Robert D. Woodberry. 2000. "The Measure of American Religion: Toward Improving the State of the Art." Social Forces 79 (1): 291-318.

Tomz, Michael, and Jessica L. Weeks. 2012. "An Experimental Investigation of the Democratic Peace." Under review.

Voas, David, and Rod Ling. 2010. "Religion in Britain and the United States." In British Social Attitudes: The 26th Report, ed. Alison Park, John Curtice, Katarina Thomson, Miranda Phillips, Elizabeth Clery, and Sarah Butt. London: Sage, 65-86.

White House. 2001. "Remarks by the President upon Arrival." News and Policies, September 16. http://news.bbc.co.uk/1/hi/ uk_politics/3536131.stm (accessed August 28, 2010).

Wike, Richard, and Brian J. Grim. 2010. "Western Views toward Muslims: Evidence from a Cross-National Survey." International Journal of Public Opinion Research 22 (1): 4-25.

Wilcox, Clyde, and Carin Larson. 2006. Onward Christian Soldiers? The Religious Right in American Foreign Policy. $3^{\text {rd }}$ ed. Boulder, CO: Westview.

Wittkopf, Eugene R. 1990. Faces of Internationalism: Public Opinion and American Foreign Policy. Durham, NC: Duke University Press.

Zaller, John R. 1992. The Nature and Origins of Mass Opinion. New York: Cambridge University Press.

Robert Johns is Senior Lecturer in Politics in the Department of Government at the University of Essex, Colchester, U.K.

Graeme A. M. Davies is Associate Professor in International Security in the School of Politics and International Studies at the University of Leeds, U.K. 